\title{
Protective Effect of Prunus mume Fermented with Mixed Lactic Acid Bacteria in Dextran Sodium Sulfate-Induced Colitis
}

\author{
Jeong-Ho Kim ${ }^{1}$, Yeong-Seon Won ${ }^{2}$, Hyun-Dong Cho ${ }^{3}$, Seong-Min Hong ${ }^{4}$, Kwang-Deog Moon ${ }^{1}$ \\ and Kwon-Il Seo ${ }^{2, *}$ \\ 1 Department of Food Science and Technology, Kyungpook National University, Daegu 41566, Korea; \\ kimjeoho90@gmail.com (J.-H.K.); kdmoon@knu.ac.kr (K.-D.M.) \\ 2 Department of Food Biotechnology, Dong-A University, Busan 49315, Korea; wonys@dau.ac.kr \\ 3 Department of Pharmacology \& Regenerative Medicine, University of Illinois, Chicago, IL 60612, USA; \\ chd0811@hanmail.net \\ 4 College of Pharmacy and Gachon Institute of Pharmaceutical Science, Gachon University, \\ Incheon 21936, Korea; homsgm0517@gmail.com \\ * Correspondence: kseo@dau.ac.kr; Tel.: +82-51-200-7565; Fax: +82-51-200-7505
}

check for

updates

Citation: Kim, J.-H.; Won, Y.-S.; Cho, H.-D.; Hong, S.-M.; Moon, K.-D.; Seo, K.-I. Protective Effect of Prunus mume Fermented with Mixed Lactic Acid Bacteria in Dextran Sodium Sulfate-Induced Colitis. Foods 2021, 10, 58. https://doi.org/10.3390/ foods 10010058

Received: 27 October 2020 Accepted: 26 December 2020 Published: 29 December 2020

Publisher's Note: MDPI stays neutral with regard to jurisdictional clai$\mathrm{ms}$ in published maps and institutional affiliations.

Copyright: (C) 2020 by the authors. Licensee MDPI, Basel, Switzerland. This article is an open access article distributed under the terms and conditions of the Creative Commons Attribution (CC BY) license (https:// creativecommons.org/licenses/by/ $4.0 /)$.

\begin{abstract}
The fruit of Prunus mume (PM) is widely cultivated in East Asia, and it has been used as a folk medication for gastrointestinal disorders, e.g., diarrhea, stomach ache and ulceration. In this study, the pectinase-treated PM juice (PJ) was fermented with Lactobacillus strains containing fundamental organic acids and free amino acids. The PJ fermented with Lactobacillus plantarum and L. casei (FP) was investigated for its protective effect in dextran sodium sulfate (DSS)-induced colitis mice model. The administration of FP reduced lipid peroxidation and histopathological colitis symptoms, e.g., shortening of the colon length, depletion of mucin, epithelial injury and ulceration, in colonic tissues. The FP-supplemented group showed the alleviation of pro-inflammatory cytokines. Compared with the DSS control group, the supplementation of FP significantly reduced the levels of serum interferon- $\gamma$ (IFN- $\gamma$ ), interleukin (IL)-1 $\beta$, IL-6, IL-12 and IL-17 as well as colonic tumor necrosis factor- $\alpha$, IFN- $\gamma$, IL-12 and IL-17. Furthermore, the DSS-induced TUNEL-positive area was significantly reduced by the FP supplementation. These results show that the supplementation of FP fermented with mixed lactic acid bacteria, L. plantarum and L. casei, elucidated the protective effect in DSS-induced colitis mice. Hence, this study suggests that FP can be utilized as a natural therapeutic agent for colitis and intestinal inflammation.
\end{abstract}

Keywords: colitis; fermentation; lactic acid bacteria; pro-inflammatory cytokine; Prunus mume

\section{Introduction}

Inflammatory bowel disease (IBD), a chronic disease, includes ulcerative colitis (UC) and Crohn's disease [1]. UC, a type of inflammatory bowel disease, is a chronic disease that affects both genders [2]. The disease occurs in the rectal and sigmoid colon and causes a decrease in body weight, diarrhea with bloody excrement and shortening of the colon length [3]. Researchers have focused on discovering the molecular mechanisms for the occurrences of this disease and identifying new therapeutic possibilities without the addition of corticosteroids, which can cause severe side effects e.g., diabetes, osteoporosis and headache $[4,5]$. Dextran sodium sulfate (DSS), a sulfated polysaccharide with an anticoagulant, -induced colitis mouse model is used widely for investigating the effects of anti-colitis therapeutic agents and natural products because aspects of the disease pathology and immune response resemble human UC.

Prunus mume fruit, also as known as maesil, meizi and ume, containing fundamental organic acids such as citric acid and malic acid, as well as various phenolic compounds, e.g., chlorogenic acid derivatives and 5-HMF, is cultivated widely in East Asia [6-8]. It has been used as a folk medication for thirst, vomiting, fever, digestion and gastrointestinal disorders $[9,10]$. The inhibitory effects of Prunus mume on intestinal inflammation have been 
reported for a decade. The Prunus mume extract decreased pro-inflammatory cytokines, which showed high radical scavenging and superoxide dismutase-like activities [11]. In a rat model of chronic cerebral hypoperfusion, the ethanol extract of Prunus mume ameliorated neurological dysfunction by inhibition of pro-inflammatory cytokines [12]. Further, Lee et al. (2017) [13] reported that Prunus mume extract showed an anti-colitis effect on DSS-induced colitis mice. However, the effect of LAB-fermented Prunus mume juice (PJ) to improve the features of colitis in mice needs to be explored.

Fermentation, which is one of the ancient methods of a processing method for food preservation globally, is a technology using microorganisms and their growth and metabolic activities in foods, leading to enhanced food qualities [14,15]. It is also a comparatively cost-effective and low-energy process [16]. Lactic acid bacteria (LAB) are one of the most popular microorganisms in food fermentation and industrial food applications because of their physiological characteristics such as high acid tolerance and broad growth temperatures ranging from 20 to $45^{\circ} \mathrm{C}$ [17]. Many resources fermented by LAB show improved functionality. Lizardo et al. (2020) [18] reported that the phytochemical content and antioxidant activities of cherry silverberry fruit was increased by fermentation with Lactobacillus plantarum KCTC 33131 and L. casei KCTC 13086. Khan et al. (2018) [19] reported that LAB-fermented dried longan contained higher phenolic and flavonoid contents and antioxidant capacities compared to unfermented dried longan. Pharmacological studies of $\mathrm{LAB}$ have been reported to convince the improvement of therapeutic effects, e.g., diarrhea, constipation and colitis [20-22]. Furthermore, LAB co-cultures could produce added value according to the increase in food quality, such as flavor and texture, and enhance functionality [23].

Therefore, in this study, the fermented Prunus mume juice with L. plantarum and L. casei (FP) containing varied free amino acids and organic acids was produced, and the physicochemical characteristics were investigated. Moreover, the protective effect of FP was evaluated by the colitis-related markers on DSS-induced colitis mice model.

\section{Material and Methods}

\subsection{Materials}

PJ used for production of FP was prepared by the method of Cho et al. (2019) [24]. Briefly, P. mume fruits purchased from the Korea Maesil Organization (Suncheon, Korea) were thoroughly washed with tap water, crushed and reacted with $0.1 \%(w / v)$ pectinase (Pectinex Ultra AFP, Novozyme, Switzerland, 10,000 Pectu/g) at $40{ }^{\circ} \mathrm{C}$ for $2 \mathrm{~h}$. After that, the samples were centrifuged at $3500 \times g$ for $15 \mathrm{~min}$ at $4{ }^{\circ} \mathrm{C}$. The supernatant was filtered and concentrated using rotary evaporator until $56-60^{\circ}$ Brix was reached. Lactobacillus plantarum KCTC 33131 and L. casei KCTC 13086 were obtained from the Korea Collection for Type Cultures (Jeongeup, Korea).

\subsection{Production of FP}

LAB-fermentation using the PJ was conducted three times by batch culture. An amount of $2.5 \mathrm{~g}$ of PJ was adjusted to $100 \mathrm{~mL}$ with distilled water (DW), and mono- and mixed cultures of L. plantarum and L. casei $(2 \%, v / v)$ were inoculated into them (Table 1$)$. Fermentation was accomplished in shaking incubator at $37^{\circ} \mathrm{C}$ and $150 \mathrm{rpm}$ for $72 \mathrm{~h}$.

Table 1. Prunus mume juice (PJ) fermentation with lactic acid bacteria (LAB).

\begin{tabular}{cccc}
\hline Strains & Lp & Lc & FP \\
\hline Lactobacillus plantarum & + & & + \\
\hline Lactobacillus casei & & + & + \\
\hline
\end{tabular}




\subsection{Total Soluble Solids, $p H$ and Cell Counting}

The changes of total soluble solids and $\mathrm{pH}$ of samples were measured every $24 \mathrm{~h}$ for fermentation time. The changes of LAB population during fermentation were determined every $24 \mathrm{~h}$ by standard plate count method.

\subsection{Organic Acid and Free Amino Acid Contents}

The analysis of organic acid contents in FP were determined by high-performance liquid chromatography (Shimadzu Co. Model Prominence, Kyoto, Japan) as previously described [8]. Briefly, the separation of organic acids was conducted using a PL Hi-Plex $\mathrm{H}$ column $\left(7.7 \times 300 \mathrm{~m}^{2}\right.$ Agilent Co., Santa Clara, CA, USA) at $65^{\circ} \mathrm{C}$. The mobile phase consisted of $5 \mathrm{mM}$ sulfuric acid with a flow rate of $0.6 \mathrm{~mL} / \mathrm{min}$. The chromatographic peak coinciding with each organic acid was identified by comparing the retention time with that of each standard.

The analysis of free amino acid contents in FP was carried out using an amino acid autoanalyzer (L-8900, Hitachi, Tokyo, Japan) with Hitachi custom ion exchange resin $\left(2622 \mathrm{SC}\right.$ PF, $\left.4.6 \times 60 \mathrm{~m}^{2}\right)$ as previously described [8]. The column was maintained at $50{ }^{\circ} \mathrm{C}$ in a column oven and the temperature of the reactor was $135^{\circ} \mathrm{C}$. For the mobile phase, a buffer set (PF-1, PF-2, PF-3, PF-4, PF-6, PF-RG, R-3 and C1, Kanto Co., Tokyo, Japan) was used with a flow rate of $1 \mathrm{~mL} / \mathrm{min}$. Each free amino acid was identified by comparing the retention time with that of amino acids mixture standard solution type AN-II and $\mathrm{B}$ (FUJIFILM Wako Pure Chemical Co., Osaka, Japan).

\subsection{Identification of Phenolic Compounds in FP}

To prepare the sample for HPLC analysis, $10 \mathrm{~mL}$ of FP was filtered with $0.45 \mu \mathrm{m}$ PVDF syringe filter and evaporated at $37^{\circ} \mathrm{C}$. The FP concentrates were diluted with DW at $20 \mathrm{mg} / \mathrm{mL}$. The phenolic compounds in FP were identified by HPLC-PDA (Waters Co., Milford, MA, USA). After $40 \mu \mathrm{L}$ of sample injection, separation was carried out with a Phenomenex Luna C18 column $\left(250 \times 4.6 \mathrm{~m}^{2}, 5 \mu \mathrm{m}\right)$. The separation process was performed in a ternary mobile phase gradient (solvent $\mathrm{A}, 0.1 \%$ trifluoroacetic acid in water; solvent $\mathrm{B}$, acetonitrile) at a flow rate of $1 \mathrm{~mL} / \mathrm{min}$. The composition of solvent $\mathrm{A}$ was maintained at $90 \%$ for $10 \mathrm{~min}$ and gradually decreased to $0 \%$ for $90 \mathrm{~min}$.

\subsection{Experimental Design}

Four-week-old male ICR mice were purchased from Hyo-Chang Science Inc. (Busan, Korea). The mice were housed in an acryl cage at $22 \pm 2{ }^{\circ} \mathrm{C}$ with free access to diet and water. All experimental animals were fed pellets of commercial chow for the experimental period. After a week of acclimation, the mice were randomly divided into six groups $(n=6)$ : normal control group, N; DSS-administered negative control group, NC; supplemented with DSS and $200 \mathrm{mg} / \mathrm{kg}$ of PJ $(2.5 \%, w / v)$ group, PJ; supplemented with DSS and 200 $\mathrm{mg} / \mathrm{kg}$ of co-cultivated with L. plantarum and L. casei group (approximately $10^{9} \mathrm{CFU} / \mathrm{mL}$ ), LAB; supplemented with DSS and $100 \mathrm{mg} / \mathrm{kg}$ of FP group, FP1; supplemented with DSS and $200 \mathrm{mg} / \mathrm{kg}$ of FP group, FP2 (Figure 1A). During the in vivo experiment, $2 \%$ of DSS was administered for induction of colitis. Samples were administered with mice from days 0 to 7 (Figure 1B). At the end of the experimental period, mice were sacrificed with $\mathrm{CO}_{2}$ gas and blood samples were collected from the inferior vena cava and placed at room temperature for $1 \mathrm{~h}$, and then centrifuged at $2500 \times \mathrm{g}$ for $20 \mathrm{~min}$ to get the serum samples. The distal portion of the colon was removed and rinsed with saline. All samples were stored at $-80^{\circ} \mathrm{C}$ in a deep freezer. All experimental animals were strictly treated according to the Dong-A University guidelines for the care and use of laboratory animals (DIACUC-18-2). 
$\mathbf{A}$

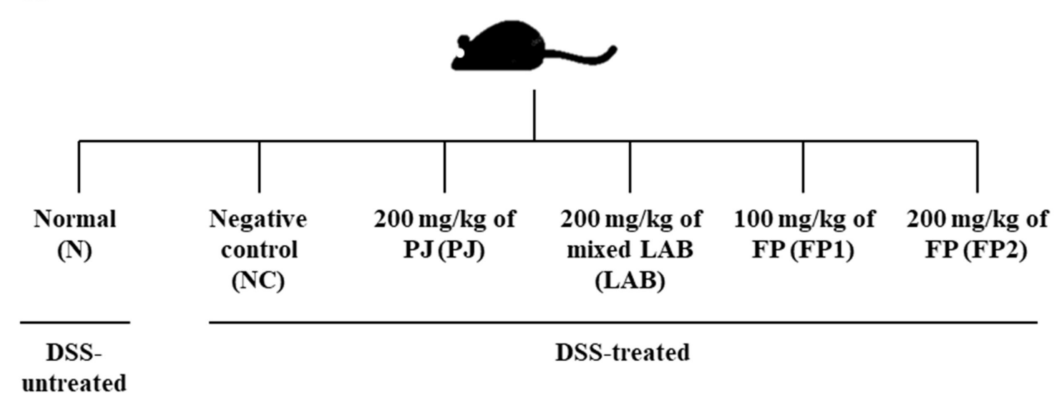

B

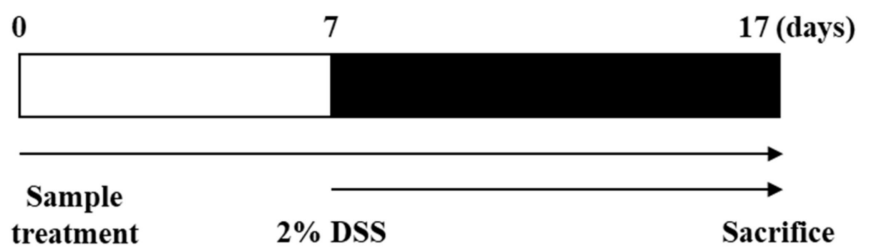

Figure 1. Scheme of the in vivo experimental design. (A) Separation of groups $(n=6)$ and (B) the schedule of dextran sodium sulfate (DSS) and sample treatment. $2 \%$ DSS was treated to induce colitis without $\mathrm{N}$ group from days 0 to 7 , then samples were treated for 10 days from days 7 to 17. Serum and organs were collected on day 17 after sacrifice.

\subsection{Lipid Peroxidation}

Lipid peroxidation was investigated by thiobarbituric acid reactive substances (TBARS) assay by the method of Hartmann et al. (2014) [24] with some modifications. The malondialdehyde (MDA) was evaluated by $0.1 \mathrm{~g}$ of liver homogenates in phosphate buffered saline. After homogenization, samples were centrifuged at $3500 \times \mathrm{g}$ at $4{ }^{\circ} \mathrm{C}$ for $10 \mathrm{~min}$, then, the supernatants were used for study. An amount of $1 \mathrm{~mL}$ of samples were mixed with $2 \mathrm{~mL}$ of thiobarbituric acid (TBA) and heated at $100{ }^{\circ} \mathrm{C}$ for $15 \mathrm{~min}$ and cooled on room temperature. The reacted samples were centrifuged at $3000 \mathrm{rpm}$ for $10 \mathrm{~min}$ and the absorbance was determined using a microplate reader (Molecular Devices, Inc., San Jose, CA, USA) at $535 \mathrm{~nm}$.

\subsection{Hematoxylin and Eosin (HEE) Staining Assay}

Histopathological analysis in colon tissue was conducted by the method described by Fischer et al. (2008) [25]. The colon samples were fixed by $4 \%$ formaldehyde solution and cut into $4 \mu \mathrm{m}$ sections, and then stained with H\&E solutions. The slides were observed using a light microscopy at $\times 100$ magnification.

\subsection{Evaluation of Inflammatory Cytokines}

To analyze inflammatory cytokines, $0.1 \mathrm{~g}$ of colon tissues were homogenized with $1 \mathrm{~mL}$ of PBS in a glass tube on ice. Then, homogenates were centrifuged for $10 \mathrm{~min}$ at $5000 \times$ $g$ to get the supernatant as samples. Serum samples were gathered by blood collected from inferior vena cava with centrifuged at $2500 \times g$ for $20 \mathrm{~min}$. The levels of TNF- $\alpha$, IFN- $\gamma$, IL$1 \beta$, IL-6, IL-12 and IL-17 in serum and colon tissues were evaluated using commercial ELISA kits according to the manufacturer's protocol (Elabscience Biotechnology Inc., Houston, TX, USA). 


\subsection{Determination of Apoptosis in Colon Tissue}

The paraffin-embedded colon tissue was cut into $4 \mu \mathrm{m}$. After deparaffinization, the slides were covered with the $0.3 \%$ of hydrogen peroxide diluted with distilled water (DW) to block endogenous peroxidase for $15 \mathrm{~min}$ at room temperature and rinsed with DW. The slides were reacted with proteinase $\mathrm{K}$ solution for $20 \mathrm{~min}$ at $37^{\circ} \mathrm{C}$. Afterwards, the terminal deoxynucleotidyl transferase solution and label solution were added to the slides. DAB solution and Mayer hematoxylin was used for development and counter stain, then dehydrated by the automated system. At least three random fields of the colonic tissues were photographed per section at $\times 200$ magnification. The TUNEL-positive area was calculated by ImageJ software (NIH).

\subsection{Statistical Analysis}

All data are analyzed as the means \pm S.D. Data were evaluated by one-way analysis of variance (ANOVA) and the statistical significances were determined using Duncan's multiple-range test at $p<0.05$.

\section{Results and Discussion}

\subsection{Changes in the Total Soluble Solids, $p H$ and Cell Count}

The physicochemical properties of the fermented Prunus mume juice with L. plantarum $(L p)$, fermented Prunus mume juice with $L$. casei $(L c)$ and FP were investigated every $24 \mathrm{~h}$. At the end of fermentation, the total soluble solids of the samples, which ranged from 1.63 to $2.12{ }^{\circ}$ Brix, suggested that FP co-cultivated with L. plantarum and L. casei showed the lowest total soluble solids (Figure 2A). The changes in the $\mathrm{pH}$ of samples were observed from $\mathrm{pH} 2.66$ to 2.72, indicating slight decreases compared to the initial value (Figure 2B). The titratable acidity of each sample, in terms of lactic acid, showed significant increases, particularly with FP from the initial titratable acidity of $0.94 \%$ to $1.11 \%$ at the end of fermentation (Figure 2C). On the other hand, there were few changes in the titratable acidity on $L p$ and $L c$ during fermentation. The FP showed significant increases in the viable lactobacillus cell count, indicating $11.22 \log \mathrm{CFU} / \mathrm{mL}$ at $24 \mathrm{~h}$ of fermentation, but the viable cell count levels had decreased at $48 \mathrm{~h}$ and $72 \mathrm{~h}$ fermentation (Figure 2D). In a previous study, Lizardo et al. (2020) [18] reported that mixed LAB-fermented cherry silverberry extract showed the effective production of viable lactobacillus compared to mono LABfermentation under harsh conditions such as acidity and low $\mathrm{pH}$. In addition, the $\mathrm{pH}$ decreased and the cell counts increased during the LAB-fermentation of kombucha [26]. Mixed-fermentation with $\mathrm{LAB}$ strains using food materials contributed to higher survival rates than mono-fermented cells. Therefore, new opportunities for the functionality of the product and resource utilization are expected [23]. Overall, these results suggest that the number of viable cells from mixed-fermentation with $L$. plantarum and L. casei was increased using the nutrients included in PJ and might be responsible for the functional properties of FP. 
A

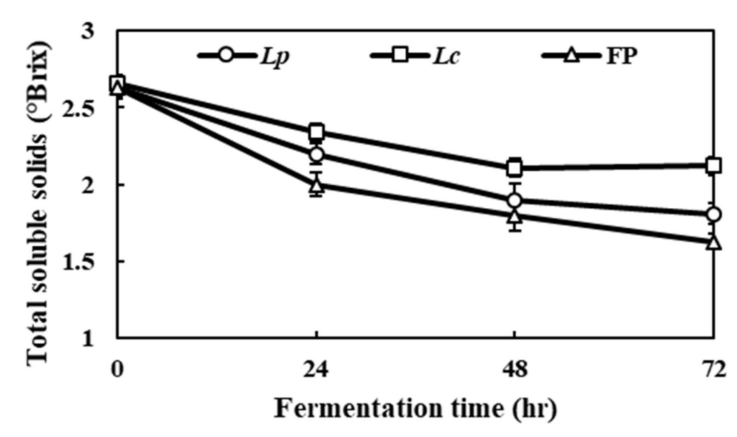

C

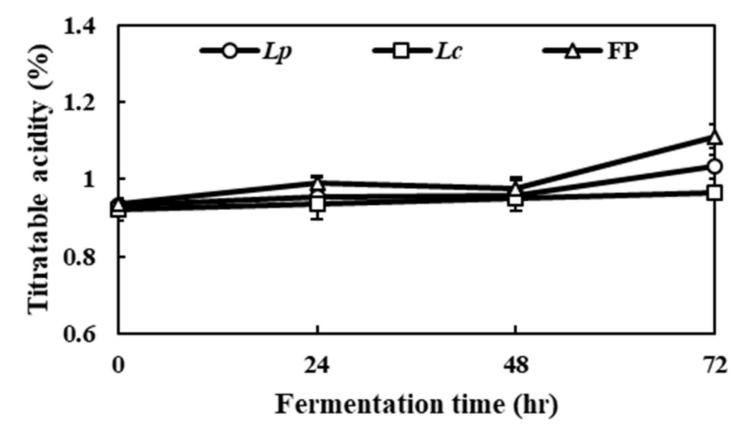

B

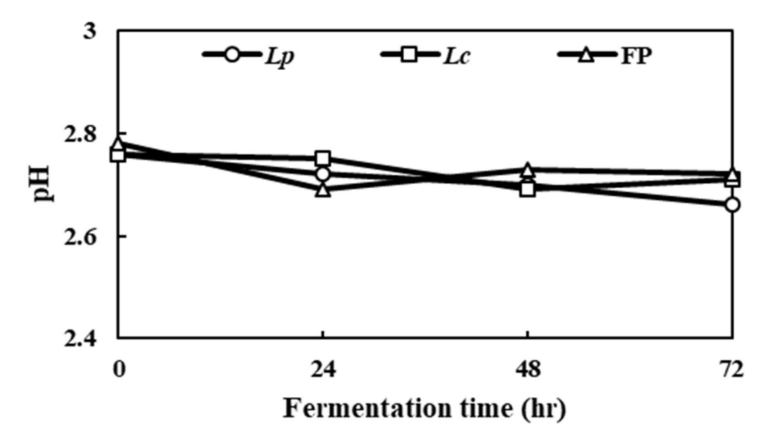

D

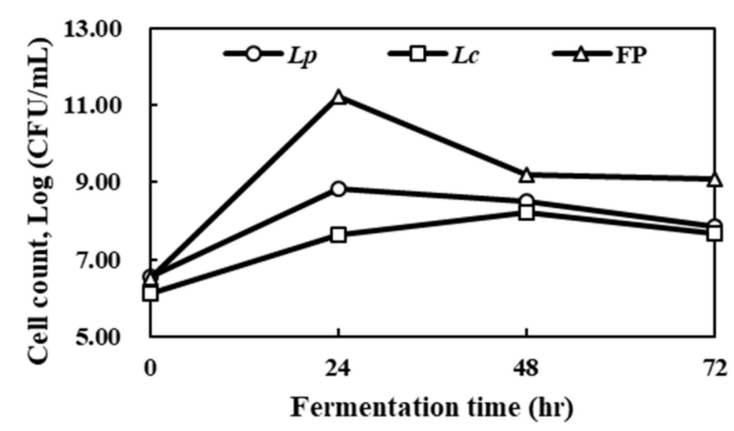

Figure 2. Changes of the physicochemical properties; (A) total soluble solids, (B) $\mathrm{pH},(\mathbf{C})$ titratable acidity and (D) viable Lactobacillus count in Prunus mume juice during fermentation with mono- and mixed cultures of L. plantarum and L. casei. Lp, fermented Prunus mume juice with L. plantarum; Lc, fermented Prunus mume juice with L. casei; FP, fermented Prunus mume juice with L. plantarum and L. casei. Data are mean \pm S.D. of three independent measurements.

\subsection{Contents of Organic Acids, Free Amino Acids and Phenolic Compounds of FP}

Prunus mume contains various organic acids, free amino acids and phenolic compounds in fresh and pomace $[8,27,28]$. The organic acids of FP contained $739.81 \mathrm{mg} \%$ of citric acid, $184.27 \mathrm{mg} \%$ of lactic acid and $71.32 \mathrm{mg} \%$ of acetic acid (Table 2). FP contains $33.32 \mathrm{ppm}, 4.35 \mathrm{ppm}, 3.39 \mathrm{ppm}$ and $2.29 \mathrm{ppm}$ of free amino acids, aspartic acid, glutamic acid, alanine and taurine, respectively. To identify the phenolic compounds in FP, HPLC analysis was carried out. The 5-HMF, neochlorogenic acid, chlorogenic acid, prunasin, benzoic acid and zingerone with concentrations of $0.65,5.18,0.99,0.52,0.56$ and $0.11 \mathrm{mg} / \mathrm{g}$, respectively, were identified by comparison with each standard phenolic acid (Figure 3). In a previous study, PJ contained a high level of organic acids such as citric acid $(969.23 \mathrm{mg} \%)$ and malic acid $(352.83 \mathrm{mg} \%)$ and free amino acids such as aspartic acid (19.66 ppm), tyrosine (1.12 ppm) and phenylalanine (0.33 ppm) [8]. Chidi et al. (2018) [29] reported changes in organic acids during fermentation. Specifically, the malic acid contents included in the fruit could be converted to lactic acid. In the previous study, the organic acids contents of PJ showed high increases of acetic acid, succinic acid and lactic acid after two-step fermentation for production of Prunus mume vinegar as a result of the metabolism of microorganisms [8]. Mazzoli et al. (2014) [17] reported that LAB on sugar fermentation produce metabolites such as lactic acid and acetic acid on their metabolic pathways. Protein degradation of the substrate during fermentation might induce changes in the free amino acid content resulting from the metabolism of microorganisms [30,31]. Adebo et al. (2020) reported the impact of fermentation on whole grains of which increased phenolics and antioxidant properties [32]. Zhao et al. (2016) reported that the phenolic compounds in tea extracts were modified by fermentation with LAB and increased antioxidant activity and cellular uptake of phenolic compounds on Caco-2 cells [33]. Therefore, these results suggest that the compositions of organic acids, free amino acids and phenolic compounds 
in FP were slightly different from those in the PJ and the protective effect of FP could be enhanced.

Table 2. Contents of organic acids and free amino acids in FP.

\begin{tabular}{cccc}
\hline Organic Acids & Contents $\mathbf{( m g} \mathbf{\%})$ & Free Amino Acids & Contents $(\mathbf{p p m})$ \\
\hline Citric acid & $739.81 \pm 17.61$ & Aspartic acid & $33.32 \pm 2.21$ \\
Lactic acid & $184.27 \pm 11.43$ & Glutamic acid & $4.35 \pm 0.74$ \\
Acetic acid & $71.32 \pm 4.52$ & Alanine & $3.39 \pm 0.35$ \\
Malic acid & N.D. & Taurine & $2.29 \pm 0.27$ \\
\hline Total organic acids & $996.07 \pm 58.82$ & Total free amino acid & $66.43 \pm 4.25$ \\
\hline
\end{tabular}

Data values are expressed as the means \pm S.D. $(n=3)$. N.D.; not detected.

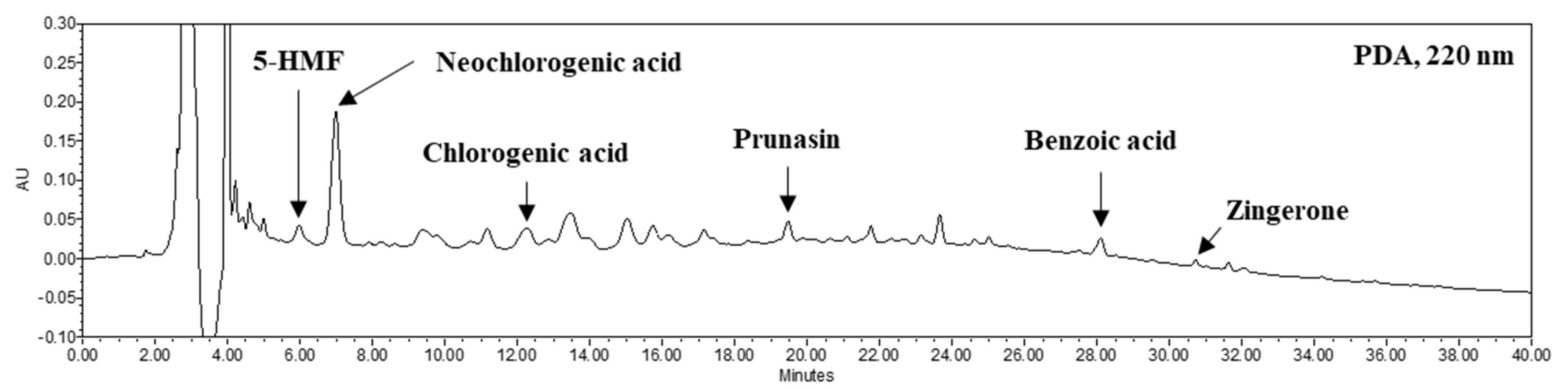

Figure 3. Phenolic compounds in FP analyzed by HPLC. 5-HMF (5.917 min); neochlorogenic acid (6.988 min); chlorogenic acid (12.244 $\mathrm{min})$; prunasin (19.466 $\mathrm{min})$; benzoic acid (28.093 min); zingerone (30.711 $\mathrm{min})$.

\subsection{Effect of FP on the Colon Length and Lipid Peroxidation}

Figure 4 shows the changes in colon length, body weight and malondialdehyde (MDA) in DSS-treated mice. The colon length of the control group treated with DSS showed a significantly shortened large intestine length compared to the normal group $(8.70 \mathrm{~cm})$. In contrast, the high dose of FP $(200 \mathrm{mg} / \mathrm{kg})$-supplemented group (FP2) showed a significantly longer colon length $(11.89 \mathrm{~cm}$ ) (Figure 4B). MDA is one of the inflammatory biomarkers related to the lipid peroxidation of tissues induced by oxidative stress, producing inflammatory markers in the damaged tissues [8,34]. Compared to the normal group, the MDA level of DSS-induced colitis mice increased significantly in the control group. The oral administration of FP1 and FP2 showed a remarkable decrease in the MDA level compared to the control group (Figure 4C). At the end of the experiment, the body weight (BW) of the normal group was $36.26 \mathrm{~g}$ and the $\mathrm{BW}$ of the control group with colitis induced by a DSS treatment was $33.61 \mathrm{~g}$ (Table 3). In previous studies, DSS-induced colitis usually causes shortening of the colon length, weight loss and histological damage to the colorectal tissues in mice [35]. Moreover, the supplementation of Boswellia serrata extract with high antioxidant activity had a protective effect on the experimental colitis model [24]. This suggests that the supplementation of FP alleviated the symptoms of colitis induced by a DSS treatment. 
A

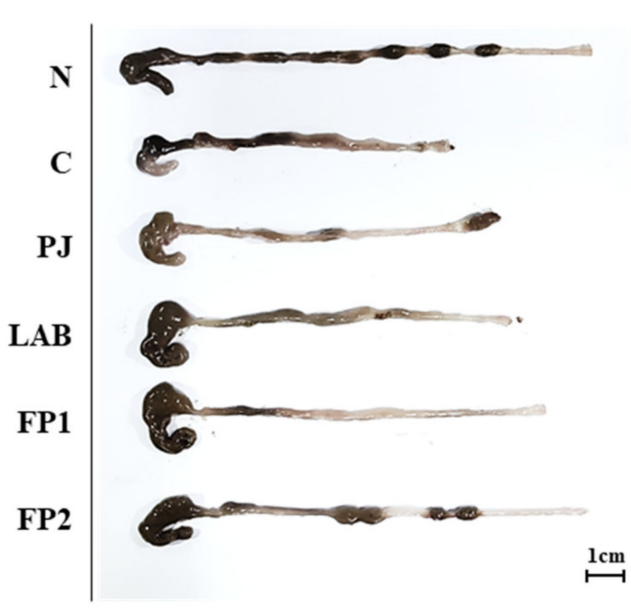

B

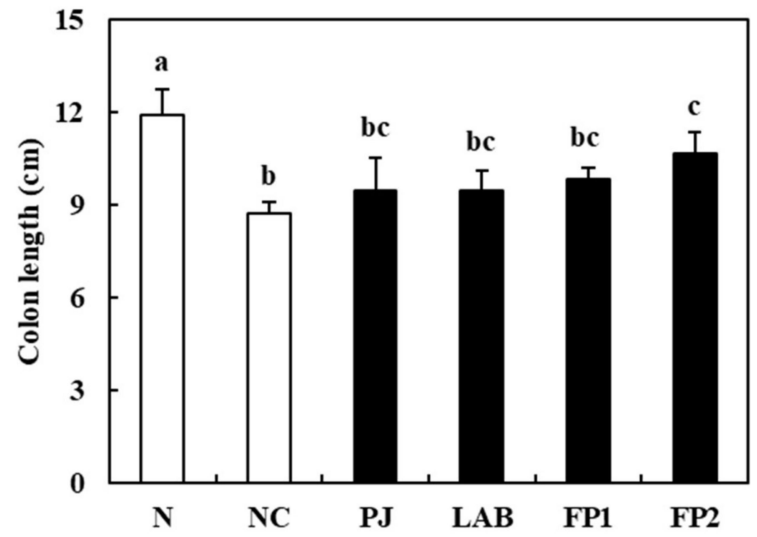

C

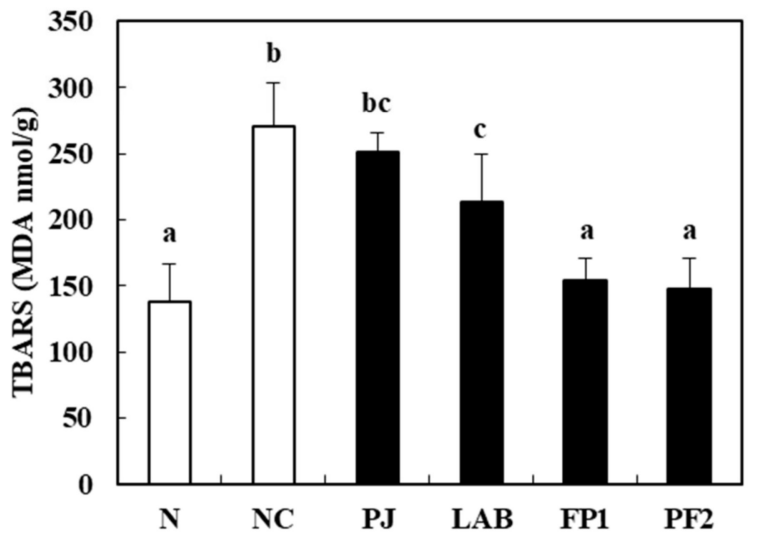

Figure 4. Colon length and lipid peroxidation after supplementation of FP to DSS-induced colitis mice. (A,B) Representative photos and length of the colons of the normal group and DSS-induced colitis mice supplemented with and without FP compared to the DSS control group. (C) Malondialdehyde contents in liver of the normal group and DSS-induced colitis mice supplemented with and without FP compared to the DSS control group. N, normal group, non-DSS treatment; NC, negative control group, DSS treatment and supplementation with distilled water; PJ; Prunus mume juice (PJ) group, DSS treatment and supplementation with $200 \mathrm{mg} / \mathrm{kg}$ of $2.5 \%$ PJ; LAB, lactic acid bacteria (LAB) group, DSS treatment and supplementation with $200 \mathrm{mg} / \mathrm{kg}$ of L. plantarum and L. casei suspended by distilled water; FP1, low dose of fermented Prunus mume juice (FP) group, DSS treatment and supplementation with $100 \mathrm{mg} / \mathrm{kg}$ of FP; FP2, high dose of FP group, DSS treatment and supplementation with $200 \mathrm{mg} / \mathrm{kg}$ of FP. Scale bars: $1 \mathrm{~cm}$. Data values are expressed as the means \pm S.D. $(n=6)$. The data are analyzed with one-way ANOVA and different letters on the bar show the difference in Duncan's multiple range test $(p<0.05)$.

Table 3. Changes of body weight after in vivo experiment.

\begin{tabular}{ccccccc}
\hline $\begin{array}{c}\text { Body- } \\
\begin{array}{c}\text { Weight } \\
(\mathbf{g})\end{array}\end{array}$ & $\mathbf{N}$ & $\mathbf{N C}$ & $\mathbf{P J}$ & LAB & FP1 & FP2 \\
\hline \multirow{2}{*}{ Initial } & $33.94 \pm$ & $34.11 \pm$ & $34.72 \pm$ & $34.71 \pm$ & $33.97 \pm$ & $34.61 \pm$ \\
& 0.81 & 0.68 & 1.04 & 0.95 & 1.65 & 1.15 \\
\hline \multirow{2}{*}{ Final } & $36.26 \pm$ & $33.61 \pm$ & $34.69 \pm$ & $35.14 \pm$ & $34.59 \pm$ & $35.61 \pm$ \\
& 1.83 & 1.82 & 3.31 & 2.32 & 3.58 & 2.52 \\
\hline
\end{tabular}

Data values are expressed as the means \pm S.D. $(n=6)$. 


\subsection{Effects of FP on Colonic Tissue Damage}

DSS is toxic to colonic tissues and induces erosions on the epithelium, ultimately impairing the barrier integrity by increasing the colonic epithelial permeability [36]. An H\&E staining assay was conducted to investigate the histological changes to the colon of DSSadministered colitis mice (Figure 5). As expected, the clear mucosa and crypt were captured in the normal group. In the DSS-induced colitis negative control group, severe damage was observed with the typical symptoms of colitis e.g., depletion of mucin, epithelial injury and ulceration. In contrast, the colon tissue of the FP-supplemented group showed increased restoration in crypt construction and epithelial erosions compared to the NC group. The supplementation of LAB-fermented rice bran alleviated the symptoms of DSS-induced colitis in mice by increasing the BW and colon length, diarrhea and inflammatory cell infiltration [37]. A Prunus mume extract had a therapeutic effect with the restoration of the crypt in colitis lesions on a DSS-administered colitis mice model [13]. This result suggests that FP administration alleviated the DSS-induced histopathological damages besides shortened colon length, loss of BW and increased lipid peroxidation in previous results.
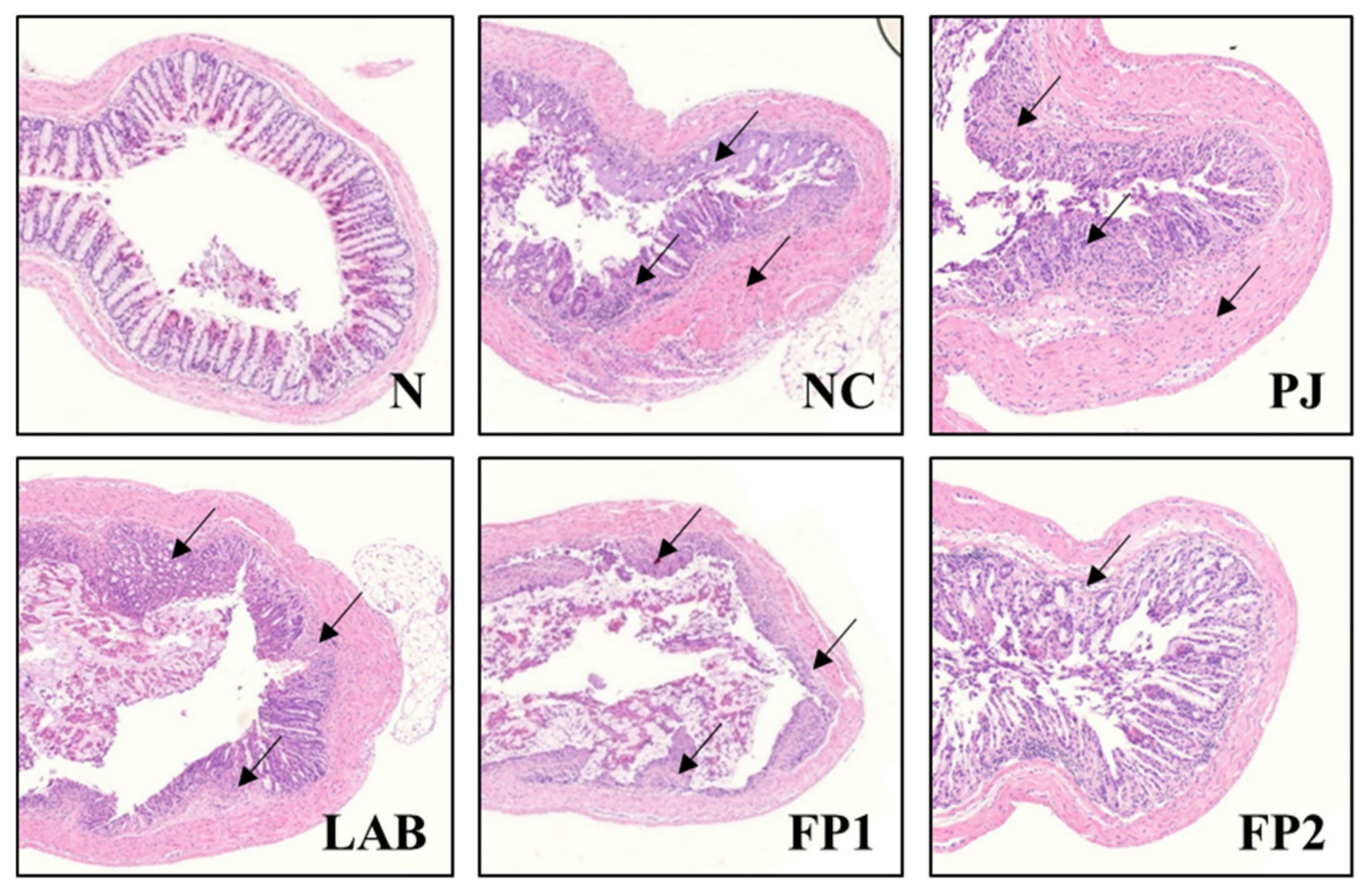

Figure 5. Effects of FP on H\&E-stained histological changes in colonic tissue to DSS-induced colitis mice. Arrows indicate damages on colonic tissues such as inflammatory cell infiltrates and epithelial erosions. Magnification: $\times 100$. N, normal group, non-DSS treatment; NC, negative control group, DSS treatment and supplementation with distilled water; PJ; Prunus mume juice (PJ) group, DSS treatment and supplementation with $200 \mathrm{mg} / \mathrm{kg}$ of $2.5 \%$ PJ; LAB, lactic acid bacteria (LAB) group, DSS treatment and supplementation with $200 \mathrm{mg} / \mathrm{kg}$ of L. plantarum and L. casei suspended by distilled water; FP1, low dose of fermented Prunus mume juice (FP) group, DSS treatment and supplementation with $100 \mathrm{mg} / \mathrm{kg}$ of FP; FP2, high dose of FP group, DSS treatment and supplementation with $200 \mathrm{mg} / \mathrm{kg}$ of FP.

\subsection{Effects of FP on the Serum Inflammatory Cytokines}

Cytokines such as interleukin (IL), tumor necrosis factor (TNF) and interferon (IFN) are regulators of infection and inflammation [38]. For that reason, many studies related to the inhibition of pro-inflammatory cytokines have been conducted to overcome the inflammation and inflammatory diseases in the human body. This study evaluated the influence of FP on serum pro-inflammatory cytokines using ELISA kits (Figure 6). The proinflammatory cytokines in the serum of the DSS-administered negative control group were significantly higher than the normal group, with significant incretion in TNF- $\alpha$, IFN- $\gamma$, IL- 
$1 \beta$, IL-6, IL-12 and IL-17. Compared to the NC group, the PJ supplemented group showed decreases in the pro-inflammatory cytokines, but there were no significant differences observed except for IL-1 $\beta$, IL-12 and IL-17. The LAB group showed a significant decrease in TNF- $\alpha$, IFN- $\gamma$, IL-6 and IL-12. As expected, supplementation of 100 and $200 \mathrm{mg} / \mathrm{kg}$ of FP decreased TNF- $\alpha$, IFN- $\gamma$, IL-1 $\beta$, IL- 6 and IL-12 significantly in DSS-treated mice. Compared to the NC group, the high dose of FP $(200 \mathrm{mg} / \mathrm{kg})$ supplemented group showed decreases in IFN- $\gamma$, IL-1 $\beta$, IL-6, IL-12 and IL-17 to $37.81 \%, 38.99 \%, 28.46 \%, 38.18 \%$ and $25.58 \%$, respectively. In a previous study, supplementation with Crytocarpa procera bark extract attenuated the colonic mucosal damage and decreased the serum IFN- $\gamma$ and IL$1 \beta$ levels in DSS-induced colitis mice [39]. Supplementation with L. fermentum CQPC04 ameliorated the myeloperoxidase activity and pro-inflammatory cytokines e.g., TNF- $\alpha$, IFN- $\gamma$, IL-1 $\beta$, IL- 6 and IL-12 in the experimental colitis model [40]. These findings suggest that the administration of FP alleviated inflammation by down-regulating the level of serum pro-inflammatory cytokines in DSS-induced colitis mice.
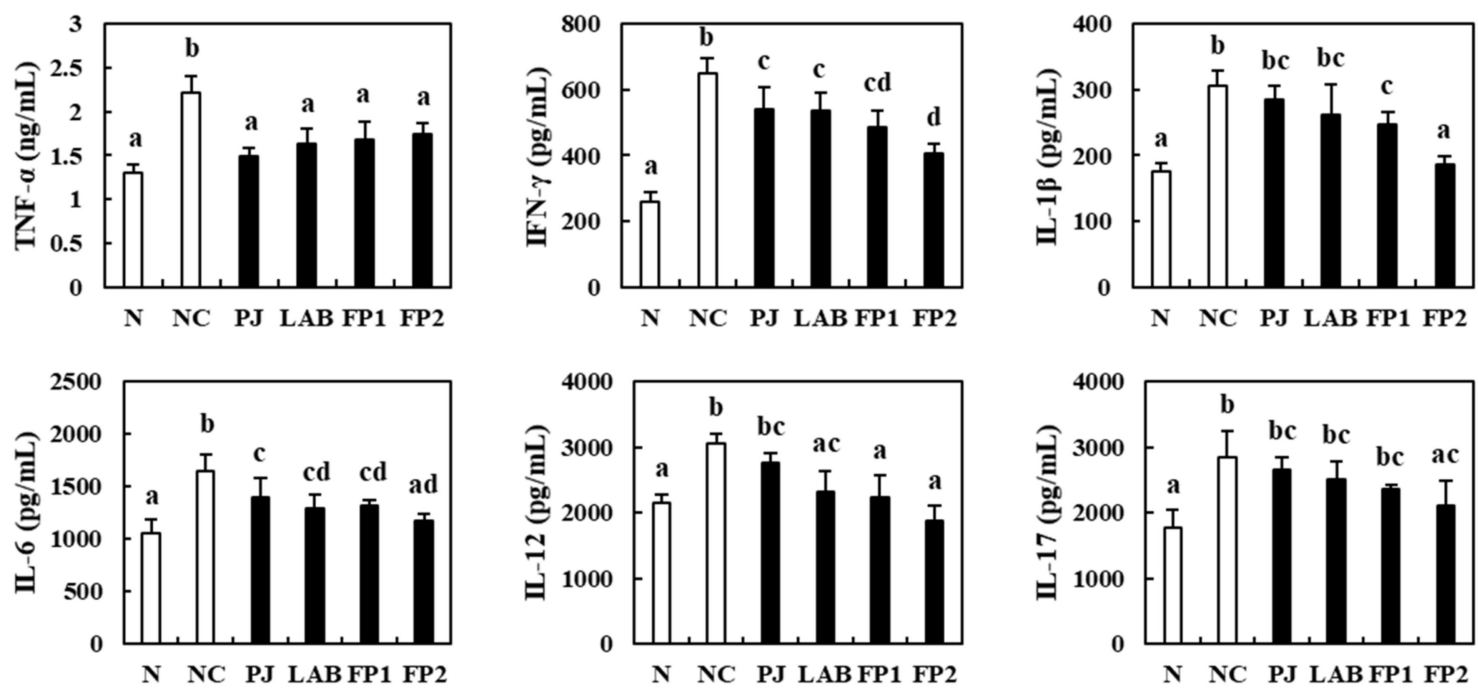

Figure 6. Effects of FP on serum cytokines of DSS-induced colitis mice. N, normal group, non-DSS treatment; NC, negative control group, DSS treatment and supplementation with distilled water; PJ; Prunus mume juice (PJ) group, DSS treatment and supplementation with $200 \mathrm{mg} / \mathrm{kg}$ of $2.5 \% \mathrm{PJ}$; LAB, lactic acid bacteria (LAB) group, DSS treatment and supplementation with $200 \mathrm{mg} / \mathrm{kg}$ of L. plantarum and L. casei suspended by distilled water; FP1, low dose of fermented Prunus mume juice (FP) group, DSS treatment and supplementation with $100 \mathrm{mg} / \mathrm{kg}$ of FP; FP2, high dose of FP group, DSS treatment and supplementation with $200 \mathrm{mg} / \mathrm{kg}$ of FP. Data values are expressed as the means \pm S.D. $(n=6)$. The data are analyzed with one-way ANOVA and different letters on the bar show the difference in Duncan's multiple range test $(p<0.05)$.

\subsection{Effects of FP on Colonic Inflammatory Cytokines}

The changes of inflammatory cytokines in the colonic tissue of DSS-induced colitis mice model were evaluated further (Figure 7). The negative control group, the DSSadministered group, showed significantly higher levels of TNF- $\alpha$, IFN- $\gamma$, IL- $1 \beta$, IL-12 and IL-17 than the normal group. In contrast, FP supplementation decreased the levels of TNF- $\alpha$, IFN- $\gamma$, IL-12 and IL-17 significantly compared to the NC group. The supplementation of PJ significantly decreased the levels of TNF- $\alpha$, IL-12 and IL-17. The LAB group showed significant decreases of TNF- $\alpha$, IFN- $\gamma$ and IL-17. Many studies on the supplementation of Lactobacillus strains have focused on ameliorating colitis by regulating cytokines and alleviating tissue damages. L. casei protected mucosa damage and modulated the immune response against intestinal inflammation in DSS-treated mice and L. plantarum increased the induction of regulatory $\mathrm{T}$ cells and type 2 helper $\mathrm{T}$ cells in the spleen and suppressed pro-inflammatory cytokines e.g., TNF- $\alpha$, IL-17 and IL-1 $\beta$ [41,42]. In addition, LAB-fermented bread showed high levels of phenolics and inhibition of the secretion 
of pro-inflammatory cytokines in vitro [43]. The functions of LAB could be multiplied with co-cultures, particularly in utilization with food [23]. This suggests that the synergistic effects of mixed fermentation with Lactobacillus strains and PJ decrease the levels of pro-inflammatory cytokines in the serum and colonic tissue in the FP-supplemented group.
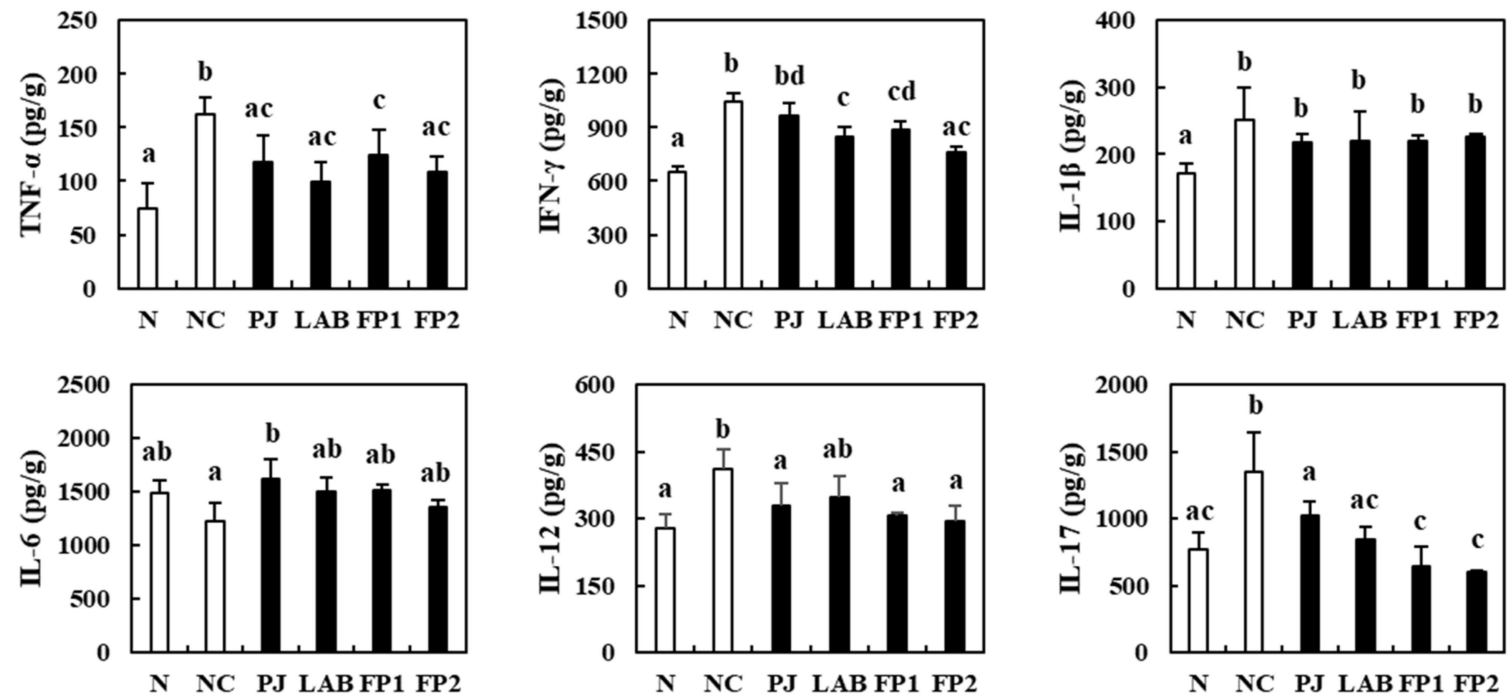

Figure 7. Effects of FP on colonic cytokines of DSS-induced colitis mice. N, normal group, non-DSS treatment; NC, negative control group, DSS treatment and supplementation with distilled water; PJ; Prunus mume juice (PJ) group, DSS treatment and supplementation with $200 \mathrm{mg} / \mathrm{kg}$ of $2.5 \%$ PJ; LAB, lactic acid bacteria (LAB) group, DSS treatment and supplementation with $200 \mathrm{mg} / \mathrm{kg}$ of L. plantarum and L. casei suspended by distilled water; FP1, low dose of fermented Prunus mume juice (FP) group, DSS treatment and supplementation with $100 \mathrm{mg} / \mathrm{kg}$ of FP; FP2, high dose of FP group, DSS treatment and supplementation with $200 \mathrm{mg} / \mathrm{kg}$ of FP. Data values are expressed as the means \pm S.D. $(n=6)$. The data are analyzed with one-way ANOVA and different letters on the bar show the difference in Duncan's multiple range test $(p<0.05)$.

\subsection{Effects of FP on Apoptosis in Colonic Tissue}

Apoptosis, one of the major points on the diagnosis of IBD, is called programmed cell death, which occurs mainly in histopathological studies in colitis lesions, accelerating the depletion of the mucosal barrier and inflammatory erosions, and the invasion of bacterial pathogens [44,45]. A TUNEL assay was carried out to evaluate the effect of FP on inhibition of apoptosis in colon tissue. The TUNEL-positive cells appeared as a brown color and normal cells appeared as a blue color. As shown in Figure 8, the TUNELpositive cells were commonly observed in the NC group indicating the induction of apoptosis by DSS supplementation. In addition, the number of apoptotic cells in the colon tissue of the PJ and LAB group, which were identified from the levels of the TUNELpositive area, was significantly lower than in the NC group. In the contrast, the TUNELpositive cells decreased significantly according to the supplementation of $100 \mathrm{mg} / \mathrm{kg}$ and $200 \mathrm{mg} / \mathrm{kg}$ of FP. Shin et al. (2017) [46] reported that rosuvastatin inhibited the induction of apoptosis activated by the pro-inflammatory cytokines secreted in the DSSinduced colitis model. Chae et al. (2019) [47] reported that the supplementation of the probiotic lactic acid bacteria, L. plantarum LB-9, ameliorated colitis by inhibiting the TNF- $\alpha$ mediated apoptosis of intestinal epithelial cells in the DSS-induced colitis mice model. Further studies will be required to probe the effects of FP on the molecular mechanisms related to the inflammatory cytokines and apoptosis. Nevertheless, based on these results, FP supplementation inhibited the apoptosis of intestinal epithelial cells activated by proinflammatory cytokines in DSS-induced colitis mice. 

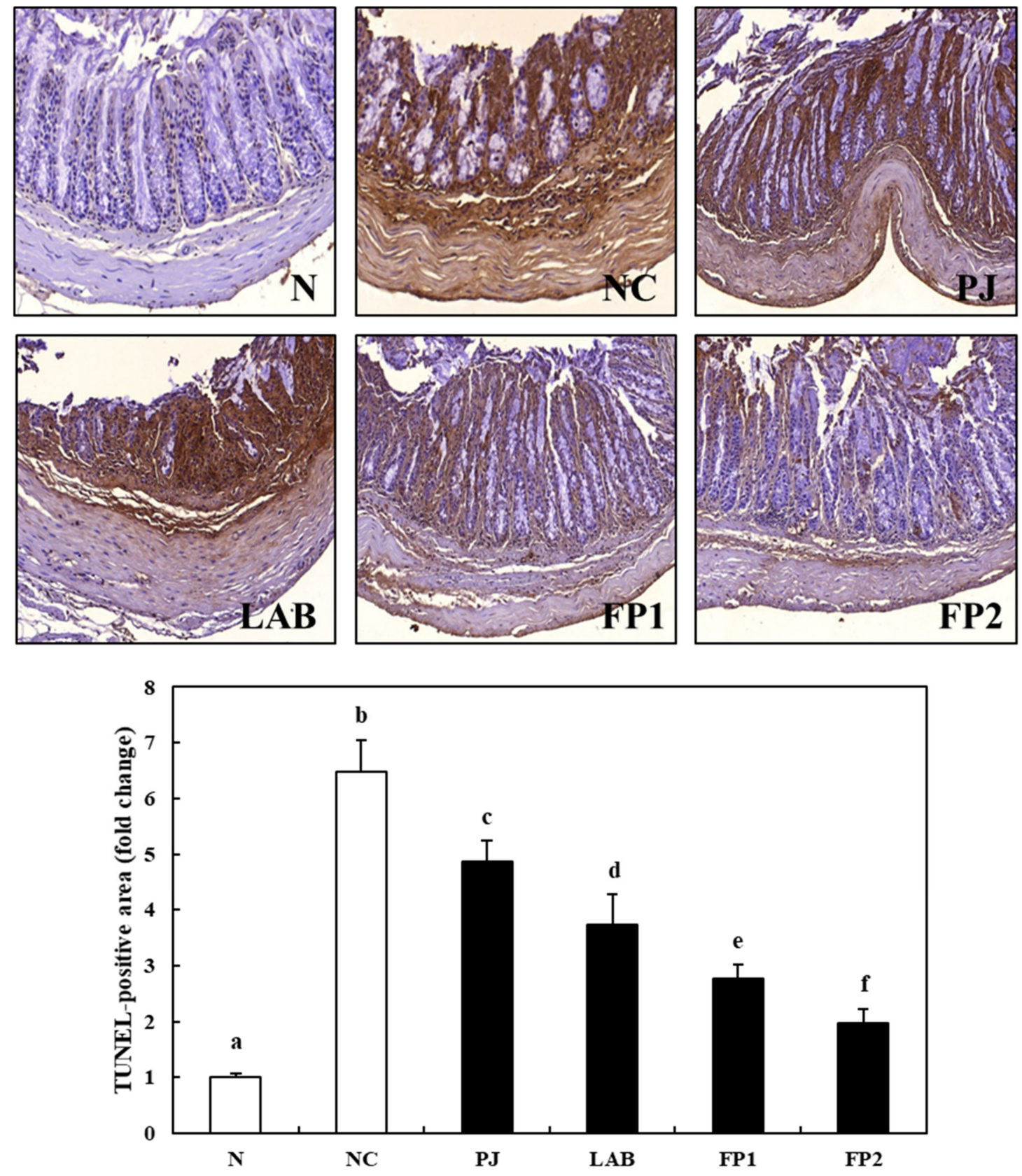

Figure 8. Effects of FP on TUNEL stained cell apoptosis in colonic tissue to DSS-induced colitis mice. Magnification: $\times 200$. $\mathrm{N}$, normal group, non-DSS treatment; NC, negative control group, DSS treatment and supplementation with distilled water; PJ; Prunus mume juice (PJ) group, DSS treatment and supplementation with $200 \mathrm{mg} / \mathrm{kg}$ of $2.5 \%$ PJ; LAB, lactic acid bacteria (LAB) group, DSS treatment and supplementation with $200 \mathrm{mg} / \mathrm{kg}$ of L. plantarum and L. casei suspended by distilled water; FP1, low dose of fermented Prunus mume juice (FP) group, DSS treatment and supplementation with $100 \mathrm{mg} / \mathrm{kg}$ of FP; FP2, high dose of FP group, DSS treatment and supplementation with $200 \mathrm{mg} / \mathrm{kg}$ of FP. Data values are expressed as the means \pm S.D. $(n=6)$. The data are analyzed with one-way ANOVA and different letters on the bar show the difference in Duncan's multiple range test $(p<0.05)$.

\section{Conclusions}

FP containing diverse free amino acids and organic acids was produced by mixed fermentation with PJ and two strains of LAB: L. plantarum and L. casei. FP supplementation prevented the typical symptoms of colitis, such as loss of BW, shortened colon length, lipid peroxidation and colonic damages. Furthermore, it attenuated the increased pro- 
inflammatory cytokines in the serum and colon in a DSS-induced colitis mice model. FP administration also inhibited the apoptosis caused by the activation of secreted proinflammatory cytokines in colon tissue. Overall, FP can be utilized as a potential source against the prevention of colitis.

Author Contributions: J.-H.K. and Y.-S.W. put together the concept and design of this study, and conducted the experiments. H.-D.C. and S.-M.H. performed formal analysis. K.-D.M. reviewed the manuscript and provided resources. K.-I.S. wrote the manuscript and supervised the study. All authors have read and agreed to the published version of the manuscript.

Funding: This research was funded by Ministry of Agriculture, Food and Rural Affairs (MAFRA) (316009-5).

Institutional Review Board Statement: Not applicable.

Informed Consent Statement: In this section, we conducted to confirm the protective effect of FP in colitis by in vivo test and informed on Section 2.6. Experimental design 'All experimental animals were strictly treated according to the Dong-A University guidelines for the care and use of laboratory animals (DIACUC-18-2)'. Not human clinical trials.

Data Availability Statement: Data is contained within the article.

Acknowledgments: This research was supported by Korea Institute of Planning and Evaluation for Technology in Food, Agriculture, Forestry (IPET) through Agri-Bio industry Technology Development Program.

Conflicts of Interest: The authors declare no conflict of interest.

\section{References}

1. Neurath, M.F. Cytokines in inflammatory bowel disease. Nat. Rev. Immunol. 2014, 14, 329-342. [CrossRef] [PubMed]

2. Kappleman, M.D.; Moore, K.R.; Allen, J.K.; Cook, S.F. Recent trends in the prevalence of Crohn's disease and ulcerative colitis in a commercially insured US population. Dig. Dis. Sci. 2013, 58, 519-525. [CrossRef] [PubMed]

3. Xue, H.; Sufit, A.J.D.; Wischmeyer, P.E. Glutamine therapy improves outcome of in vitro and in vivo experimental colitis model. J. Parenter. Enteral. Nutr. 2011, 35, 188-197. [CrossRef] [PubMed]

4. Vukelić, I.; Detel, D.; Pućar, L.B.; Potoćnjak, I.; Buljević, S.; Domitrović, R. Chlorogenic acid ameliorates experimental colitis in mice by suppressing signaling pathways involved in inflammatory response and apoptosis. Food Chem. Toxicol. 2018, 121, 140-150. [CrossRef] [PubMed]

5. Abraham, B.P.; Ahmed, T.; Ali, T. Inflammatory bowel disease: Pathophysiology and current therapeutic approaches. In Gastrointestinal Pharmacology; Springer: Boston, MA, USA, 2017; pp. 115-146.

6. Na, J.R.; Oh, K.N.; Park, S.U.; Bae, D.H.; Choi, E.J.; Jung, M.A.; Choi, C.Y.; Lee, D.W.; Jun, W.J.; Lee, K.Y.; et al. The laxative effects of maesil (Prunus mume Siebold \& Zucc.) on constipation induced by a low-fibre diet in a rat model. Int. J. Food Sci. Nutr. 2013, 64, 333-345.

7. Hwang, J.Y.; Ham, J.W.; Nam, S.H. The antioxidant activity of maesil (Prunus mume). Korean J. Food Sci. Technol. 2004, 36, 461-464.

8. Chuda, Y.; Ono, H.; Ohnishi-Kameyama, M.; Matsumoto, K.; Nagata, T.; Kikuchi, Y. Mumefural, citric acid derivate improving blood fluidity from fruit-juice concentrate of Japanese apricot (Prunus mume Sieb. et Zucc). J. Agric. Food Chem. 1999, 47, 828-831. [CrossRef]

9. Debnath, T.; Kim, D.H.; Lim, B.O. Natural products as a source of anti-inflammatory agents associated with inflammatory bowel disease. Molecules 2013, 18, 7253-7270. [CrossRef]

10. Kim, M.S.; Bang, J.H.; Lee, J.; Han, J.S.; Kang, H.W.; Jeon, W.K. Fructus mume ethanol extract prevents inflammation and normalized the septohippocampal cholinergic system in a rat model of chronic cerebral hypoperfusion. J. Med. Food 2016, 19, 196-204. [CrossRef]

11. Lee, S.Y.; Lee, S.J.; Hur, S.J. Effects of Prunus mume Sieb. et Zucc. Extract and its biopolymer encapsulation on a mouse model of colitis. J. Sci. Food Agric. 2017, 97, 686-692. [CrossRef]

12. Nuraida, L. A review: Health promoting lactic acid bacteria in traditional Indonesian fermented foods. Food Sci. Hum. Wellness 2015, 4, 47-55. [CrossRef]

13. Feng, Y.; Zhang, M.; Mujumdar, A.S.; Gao, Z. Recent research process of fermented plant extract: A review. Trends Food Sci. Technol. 2017, 65, 40-48. [CrossRef]

14. Chaves-López, C.; Serio, A.; Paparella, A.; Martuscelli, M.; Corsetti, A.; Tofalo, R.; Suzzi, G. Impact of microbial cultures on proteolysis and release of bioactive peptides in fermented milk. Food Microbiol. 2014, 42, 117-121. [CrossRef] [PubMed]

15. Mazzoli, R.; Bosco, F.; Mizrahi, I.; Bayer, E.A.; Pessione, E. Towards lactic acid bacteria-based biorefineries. Biotechnol. Adv. 2014, 32, 1216-1236. [CrossRef] [PubMed] 
16. Lizardo, R.C.M.; Cho, H.D.; Won, Y.S.; Seo, K.I. Fermentation with mono- and mixed cultures of Lactobacillus pllantarum and L. casei enhances the phytochemical content and biological activities of cherry silverberry (Elaeagnus multiflora Thunb.) fruit. J. Sci. Food Agric. 2020, 100, 3687-3696. [CrossRef] [PubMed]

17. Khan, S.A.; Liu, L.; Lai, T.; Zhang, R.; Wei, Z.; Xiao, J.; Deng, Y.; Zhang, M. Phenolic profile, free amino acids composition and antioxidant potential of dried longan fermented by lactic acid bacteria. J. Food Sci. Technol. 2018, 55, 4782-4791. [CrossRef] [PubMed]

18. Li, Y.T.; Xu, H.; Ye, J.Z.; Wu, W.R.; Shi, D.; Fang, D.Q.; Liu, Y.; Li, L.J. Efficacy of Lactobacillus rhamnosus GG in treatment of acute pediatric diarrhea: A systematic review with meta-analysis. World J. Gastroenterol. 2019, 25, 4999-5016. [CrossRef]

19. Yi, R.; Peng, P.; Zhang, J.; Du, M.; Lan, L.; Qian, Y.; Zhou, J.; Zhao, X. Lactobacillus plantarum CQPC02-fermented soybean milk improves loperamide-induced constipation in mice. J. Med. Food 2019, 22, 1208-1221. [CrossRef]

20. The role of probiotic lactic acid bacteria and bifidobacteria in the prevention and treatment of inflammatory bowel disease and other related diseases: A systematic review of randomized human clinical trials. Biomed. Res. Int. 2015, 2015, 505878.

21. Canon, F.; Nidelet, T.; Guédon, E.; Thierry, A.; Gagnaire, V. Understanding the mechanisms of positive microbial interactions that benefit lactic acid bacteria co-cultures. Front. Microbiol. 2020, 11, 2088. [CrossRef]

22. Cho, H.D.; Kim, J.H.; Won, Y.S.; Moon, K.D.; Seo, K.I. Inhibitory effects of pectinase-treated Prunus mume fruit concentrate on colorectal cancer proliferation and angiogenesis of endothelial cells. J. Food Sci. 2019, 84, 3284-3295. [CrossRef] [PubMed]

23. Kim, J.H.; Cho, H.D.; Won, Y.S.; Hong, S.M.; Moon, K.D.; Seo, K.I. Anti-fatigue effect of Prunus mume vinegar in high-intensity exercised rats. Nutrients 2020, 12, 1205. [CrossRef] [PubMed]

24. Hartmann, R.M.; Fillmann, H.S.; Martins, M.I.M.; Meurer, L.; Marroni, N.P. Boswellia serrata has beneficial anti-inflammatory and antioxidant properties in a model of experimental colitis. Phytother. Res. 2014, 28, 1392-1398. [CrossRef] [PubMed]

25. Fischer, A.H.; Jacobson, K.A.; Rose, J.; Zeller, R. Hematoxylin and eosin staining of tissue and cell sections. CSH Protoc. 2008, 2008. [CrossRef]

26. Elkhtab, E.; El-Alfy, M.; Shenana, M.; Mohamed, A.; Yousef, A.E. New potentially antihypertensive peptides liberated in milk during fermentation with selected lactic acid bacteria and kombucha cultures. J. Dairy Sci. 2017, 100, 9508-9520. [CrossRef]

27. Cha, H.S.; Hwang, J.B.; Park, J.S.; Park, Y.K.; Jo, J.S. Changes in chemical composition of mume (Prunus mume Sieb. et Zucc) fruits during maturation. Korean J. Food Preserv. 1999, 12, 481-487.

28. Mitani, T.; Horinishi, A.; Kishida, K.; Kawabata, T.; Yano, F.; Mimura, H.; Inaba, N.; Yamanishi, H.; Oe, T.; Negoro, K.; et al. Phenolics profile of mume, Japanese apricot (Prunus mume Sieb. et Zucc.) fruit. Biosci. Biotechnol. Biochem. 2013, 77, $1623-1627$. [CrossRef]

29. Chidi, B.S.; Bauer, F.F.; Rossouw, D. Organic acid metabolism and the impact of fermentation practices on wine acidity-A review. S. Afr. J. Enol. Cotoc. 2018, 39, 315-329. [CrossRef]

30. Erbas, M.; Ertugay, M.F.; Erbas, M.O.; Certel, M. The effect of fermentation and storage on free amino acids of tarhana. Int. J. Food Sci. Nutr. 2005, 56, 349-359. [CrossRef]

31. We, C.; Huang, J.; Zhou, R. Genomics of lactic acid bacteria: Current status and potential applications. Crit. Rev. Microbiol. 2017, 43, 393-404.

32. Adebo, O.A.; Medina-Meza, I.G. Impact of fermentation on the phenolic compounds and antioxidant activity of whole cereal grains: A mini review. Molecules 2020, 25, 927. [CrossRef] [PubMed]

33. Zhao, D.; Shah, N.P. Lactic acid bacterial fermentation modified phenolic composition in tea extracts and enhanced their antioxidant activity and cellular uptake of phenolic compounds following in vitro digestion. J. Funct. Foods 2016, 20, 182-194. [CrossRef]

34. Sangaraju, R.; Nalban, N.; Alavala, S.; Rajendran, V.; Jerald, M.K.; Sistla, R. Protective effect of galangin against dextran sulfate sodium (DSS)-induced ulcerative colitis in Balb/c mice. Inflamm. Res. 2019, 68, 691-704. [CrossRef] [PubMed]

35. Murano, M.; Maemura, K.; Hirata, K.; Toshina, K.; Nishikawa, T.; Hanamoto, N.; Sasaki, S.; Saitoh, O.; Katsu, K. Therapeutic effect of intracolonically administered nuclear factor $\mathrm{kB}$ (p65) antisense oligonucleotide on mouse dextran sulphate sodium (DSS)-induced colitis. Clin. Exp. Immunol. 2000, 120, 51-58. [CrossRef]

36. Chassaing, B.; Aitken, J.D.; Malleshappa, M.; Vijay-Kumar, M. Dextran sulfate sodium (DSS)-induced colitis in mice. Curr. Protoc. Immunol. 2015, 104, 15.25.1-15.25.14. [CrossRef]

37. Islam, J.; Koseki, T.; Watanabe, K.; Ardiansyah, A.; Budijanto, S.; Oikawa, A.; Alauddin, M.; Goto, T.; Aso, H.; Komai, M.; et al. Dietary supplementation of fermented rice bran effectively alleviates dextran sodium sulfate-induced colitis in mice. Nutrients 2017, 9, 747. [CrossRef]

38. Dinarello, C.A. Proinflammatory cytokines. Chest 2000, 118, 503-508. [CrossRef]

39. Mario, R.C.; Elizdath, M.G.; Alma, D.N.T.; Luvia, E.S.T.; Leticia, G.S.; Maria, M.C.M.; Luis, I.T.; Marco, A.R.M. Anti-inflammatory and antioxidant activities of the methanolic extract of Cyrtocarpa procera bark reduces the severity of ulcerative colitis in a chemically induced colitis model. Mediat. Inflamm. 2020, 2020, 5062506.

40. Zhou, X.; Liu, H.; Zhang, J.; Mu, J.; Zalan, Z.; Hegyi, F.; Takacs, K.; Zhao, X.; Du, M. Protective effect of Lactobacillus fermentum CQPC04 on dextran sulfate sodium-induced colitis in mice is associated with modulation of the nuclear factor- $\mathrm{KB}$ signaling pathway. J. Dairy Sci. 2019, 102, 9570-9585. [CrossRef]

41. Park, J.S.; Joe, I.S.; Rhee, P.D.; Jeong, C.S.; Jeong, G.J. A lactic acid bacterium isolated from kimchi ameliorates intestinal inflammation in DSS-induced colitis. J. Microbiol. 2017, 55, 304-310. [CrossRef] 
42. Cui, Y.; Wei, H.; Lu, F.; Liu, X.; Liu, D.; Gu, L.; Ouyang, C. Different effects of three selected Lactobacillus strains in dextran sulfate sodium-induced colitis in BALB/c mice. PLoS ONE 2016, 11, e0148241. [CrossRef] [PubMed]

43. Nunzio, M.D.; Picone, G.; Pasini, F.; Chiarello, E.; Caboni, M.F.; Capozzi, F.; Gianotti, A.; Bordoni, A. Olive oil by-product as functional ingredient in bakery products. Influence of processing and evaluation of biological effects. Food Res. Int. 2020, 131, 108940. [CrossRef] [PubMed]

44. Zhu, L.; Gu, P.Q.; Shen, H. Gallic acid improved inflammation via NF-kB pathway in TNBS-induced ulcerative colitis. Int. Immunopharmacol. 2019, 67, 129-137. [CrossRef] [PubMed]

45. Wang, Y.; Wang, Y.; Shen, W.; Wang, Y.; Cao, Y.; Nuerbulati, N.; Chen, W.; Lu, G.; Xiao, W.; Qi, R. Grape seed polyphenols ameliorated dextran sulfate sodium-induced colitis cia suppression of inflammation and apoptosis. Pharmacology 2020, 105, 9-18. [CrossRef]

46. Shin, S.K.; Cho, J.H.; Kim, E.J.; Kim, E.K.; Park, D.K.; Kwon, K.A.; Chung, J.W.; Kim, K.O.; Kim, Y.J. Anti-inflammatory and anti-apoptotic effects of rosuvastatin by regulation of oxidative stress in a dextran sulfate sodium-induced colitis model. World $J$. Gastroenterol. 2017, 23, 4559-4568. [CrossRef]

47. Chae, J.M.; Chang, M.H.; Heo, W.; Cho, H.T.; Lee, D.H.; Hwang, B.B.; Kim, J.W.; Yoon, S.M.; Yang, S.Y.; Lee, J.H.; et al. LB-9, novel probiotic lactic acid bacteria, ameliorates dextran sodium sulfate-induced colitis in mice by inhibiting TNF- $\alpha$-mediated apoptosis of intestinal epithelial cells. J. Med. Food 2019, 22, 271-276. [CrossRef] 